\title{
Keanekaragaman Jenis dan Kepadatan Zooplankton di Perairan Pulau Makassar Kota Baubau
}

\author{
Ismail Failu ${ }^{1}$, Azelia Monica Azizu ${ }^{1}$, Kasman ${ }^{1}$, Sofyan ${ }^{1}$ \\ ${ }^{1}$ Fakultas Pertanian, Universitas Muhammadiyah Buton, Indonesia \\ *Korespondensi: ismailfailu56@gmail.com
}

\begin{tabular}{|c|c|}
\hline & \multirow{10}{*}{ 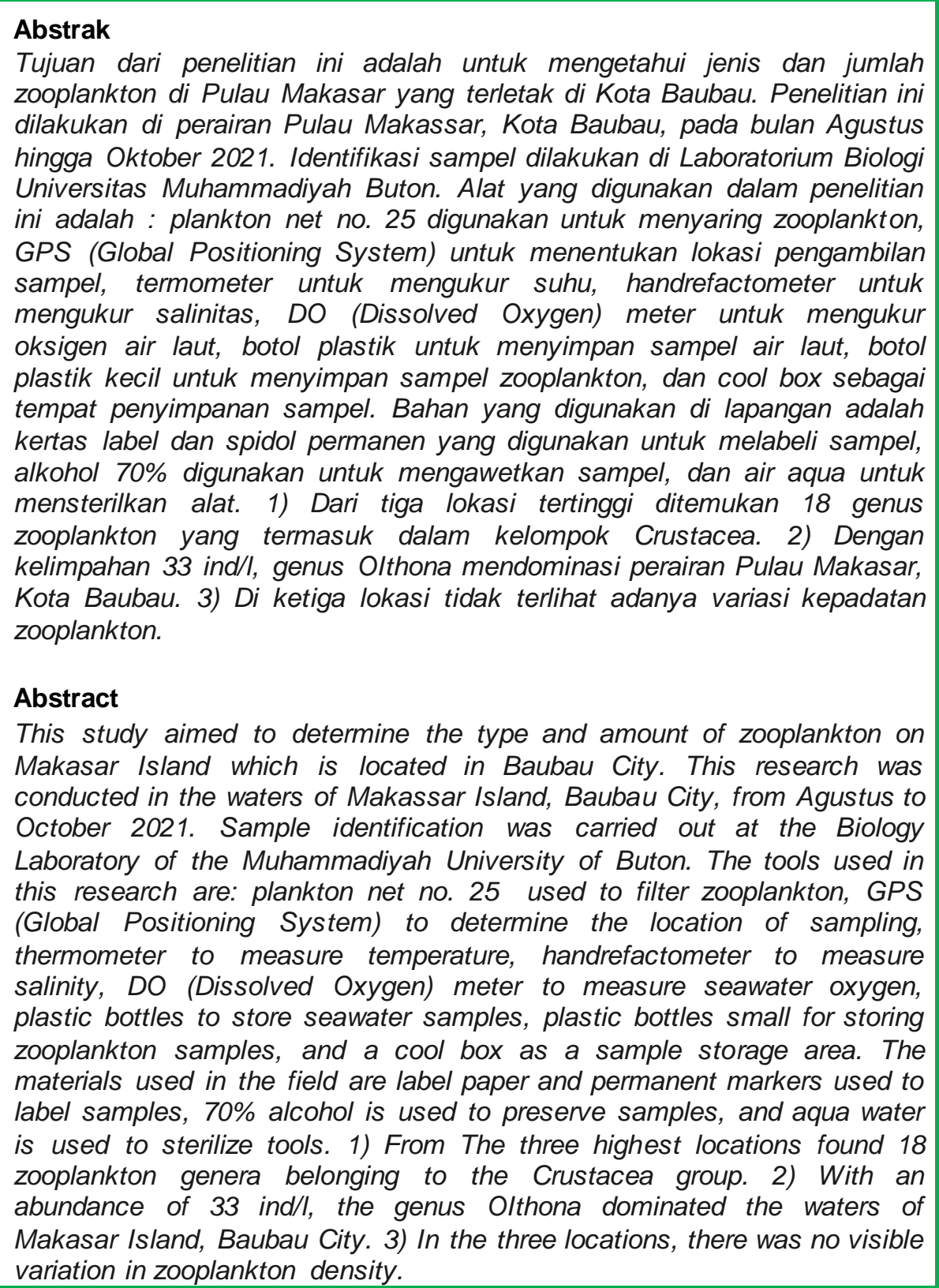 } \\
\hline Diterin & \\
\hline & \\
\hline & \\
\hline & \\
\hline & \\
\hline & \\
\hline & \\
\hline & \\
\hline & \\
\hline
\end{tabular}




\section{Pendahuluan}

Air laut memiliki fungsi yang memungkinkan adanya kehidupan di dalamnya. Air adalah media yang menguntungkan untuk aktivitas biologis dalam produksi dan degradasi bahan organik dari sudut pandang biologis. Pengelolaan kualitas air adalah proses menyesuaikan kondisi lingkungan untuk mendorong pertu mbuhan atau produktivitas ikan. Air dikatakan berkualitas jika memiliki tingkat kesuburan yang tinggi. Dalam konteks ini adalah tentang keberadaan plankton, khususnya fitoplankton, yang meru pakan produktivitas utama dalam rantai makanan.

Plankton adalah makhluk mikroskopis yang mengapung mengikuti arus laut. Plankton di air dapat dibagi menjadi dua jenis: fitoplankton dan zooplankton. Fitoplankton adalah komponen autotrof plankton. Autotrof adalah organisme yang mampu menyediakan/mensintesis makanan sendiri yang berupa bahan organik dari bahan anorganik dengan bantuan energi seperti matahari dan kimia. Komponen autotrof berfungsi sebagai produsen, sedangkan zooplankton adalah makhluk yang hidupnya mengapung bersama pergerakan air dari tubuh hewan (Rahayu, 2009). Sama seperti fitoplankton adalah produsen utama (pemasok energi di tingkat tropis yang lebih tinggi), zooplankton memainkan peran penting dalam mempertahankan energi (Castro \& Huber, 2007).

Plankton dapat dijumpai hampir semua wilayah lautan dengan kekayaan dan komposisi yang berubah. Kekayaan dan komposisinya berubah tergantung pada kondisi alam. Beberapa komponen alam abiotik seperti parameter fisika-kimia (suhu, peningkatan cahaya, rasa asin, dan $\mathrm{pH}$ ) merupakan variabel yang berperan penting dalam menentukan perkembangbiakan zooplankton di perairan. Dalam perkembangannya, variabel biotik seperti aksesibilitas guling (fitoplankton) dan jumlah pemangsa serta perilaku spesies zooplankton dalam memperebutkan makanan merupakan komponen lain yang dapat mempengaruhi kekayaan dan komposisi spesies zooplankton itu sendiri (Japa et al., 2013).

Larva ikan merupakan salah satu jenis organisme pemakan zooplankton. Menurut penelitian (Revika et al., 2016), Gobiopterus zooplankton merupakan sumber pakan alami bagi ikan laut. Sebagai mana diketahui bahwa zooplankton sebagai penyalur energi dari zooplankton menuju larva-larva ikan kecil serta organisme lain. Zooplankton berperan sebagai makanan untuk biota-biota perairan sehingga kestabilan ekosistem tetap terjaga (Raza'l, 2017).

Perairan laut Pulau Makassar Kota Baubau, menjadi spot populer bagi ikan kerapu. Kerapu adalah jenis ikan yang dapat ditemukan di hampir setiap badan air. Terutama di pulau Makassar, kota Baubau Sulawesi Tenggara. Keberadaan zooplankton yang menjadi makanan larva kerapu sangat menentukan kelangsungan hidup dan perkembangan kerapu.

Untuk menjelaskan hal tersebut, dilakukan studi pendahuluan untuk mengetahui jenis dan jumlah zooplankton sebagai pakan alami larva kerapu, meskipun penelitian zooplankton di perairan tersebut belum banyak dilakukan. 


\section{Metode Penelitian}

\subsection{Waktu dan lokasi Penelitian}

Agustus hingga Oktober 2021, penelitian ini dilakukan di perairan Pulau Makassar, Kota Baubau. Identifikasi sampel dilakukan di Laboratorium Biologi Universitas Muhammadiyah Buton.

\subsection{Komponen dan Peralatan}

\section{a. Lapangan}

Dalam penelitian ini, alat yang digunakan di lapangan sebagai berikut: jaring plankton no. 25 sebagai penyaringan zooplankton, GPS (Global Positioning System) sebagai penentuan lokasi pengambilan sampel, termometer sebagai pengukuran temperatur, handrefactometer sebagai pengukuran kadar garam, DO (Dissolved Oxygen) meter sebagai pengukuran oksigen air laut, botol plastik sebagai penyimpanan contoh tes air laut, botol plastik kecil sebagai penyimpanan contoh tes zooplankton.

Bahan bahan yang di gunakan dilapangan yakni kertas stiker digunakan sebagai penandaan sampel, alkohol $70 \%$ digunakan sebagai pengawetan sampel, dan air mineral digunakan untuk mensterilkan alat.

\section{b. Laboratorium}

Mikroskop digunakan sebagai pengidentifikasian sampel zooplankton, hemasitometer sebagai perhitungan sampel zooplankton, kaca penutup digunakan untuk menutupi Sedwick rafter counter (SCR), tisu digunakan sebagai pembersihan kotoran,

Buku Marine Zooplankton Practical Guide for the Northwestern Arabian Gulf Volume 1 dan 2 digunakan di laboratorium sebagai panduan untuk mengidentifikasi spesies zooplankton

\subsection{Prosedur Penelitian}

Prosedur pelaksanaan penelitian ini meliputi perlengkapan, persediaan dan peninjauan lapangan serta penetapan lokasi, proses pengambilan sampel air, analisis data dan pembuatan hasil laporan akhir.

\section{a. Tahap Persiapan}

Survei lapangan pendahuluan dan tinjauan pustaka untuk mendapatkan gambaran yang baik tentang keadaan lokasi penelitian secara keseluruhan dan untuk mempersiapkan peralatan penelitian.

\section{b. Tahap Penentuan Spot}

Spot penelitian didirikan di laut Pulau Makassar, Kota Baubau, berdasarkan wilayah tempat budidaya ikan dilakukan.

Posisi kawasan padang lamun yang dekat dengan habitat karang dengan substrat berpasir, kawasan padang lamun dengan substrat pasir, dan kawasan yang tertutup ekosistem lamun dan karang ditentukan di tiga perairan budidaya ikan. Dengan mengumpulkan sampel air laut, peneliti dapat membandingkan jumlah zooplankton di tiga lokasi. 


\section{c. Pengambilan sampel}

Zooplankton diambil sampelnya dalam 20 liter air laut kemudian disaring dengan plankton net. Temuan disaring kemudian ditempatkan dalam botol $25 \mathrm{ml}$ dan diawetkan dengan tiga tetes alkohol $70 \%$ untuk identifikasi di laboratorium.

1) Analisis Sampel

Perlu menggunakan Sedwick rafter counter (SRC) untuk mendeteksi dan menghitung jumlah zooplankton dengan mengisi pipet dengan air sampai terisi penuh dan tidak ada gelembung udara di bawah tutup sel SRC. Sel-sel SRC kemudian diperiksa di bawah lensa pembesar pada amplifikasi pada amplifikasi 40 atau 100 kali ukuran aslinya. Setiap contoh tes diuji lima kali (Anugerah Nontji, 2006).

2) Rumus berikut digunakan untuk menentukan keanekaragaman jenis, frekuensi, indeks keanekaragaman, indeks dominasi, dan indeks keseragaman:

\subsection{Komposisi Jenis}

Rumus berikut digunakan untuk menghitung komposisi spesies (Boyd, 1979): Jenis Komposisi $(\%)=\frac{m i}{N} x 100 \%$

Dimana :

ni : Jumlah total individu yang diamati untuk setiap spesies.

$\mathrm{N}$ : Jumlah semua individu

\section{a. Kelimpahan Zooplankton}

Perhitungan zooplankton pada S-R menggunakan rumus (Boyd, 1979):

Jumlah individu/ml $=\frac{C x 1000}{L X D X W S}$

Dimana :

$C$ : Jumlah individu yang ditemukan

$\mathrm{L}$ : Panjang alur S-R $(50 \mathrm{~mm})$

$\mathrm{D}$ : Tinggi alur S-R $(1 \mathrm{~mm})$

W : Lebar alur $(20 \mathrm{~mm})$

S : Jumlah alur yang dihitung (1000 alur)

\section{b. Indeks Keanekaragaman}

Rumus berikut digunakan untuk menghitung indeks keanekaragaman : "Shannon Indeks of Diversity" (Odum, 1983).

$$
\mathrm{H}^{\prime}=-\varepsilon \frac{n i}{N} \operatorname{Ln} \frac{n i}{N}
$$

Dimana:

$\mathrm{H}^{\prime}$ : Indeks Keanekaragaman

ni : Jumlah individu setiap jenis

$\mathrm{N}$ : Jumlah individu seluruh spesies 
Seluruh rentang Indeks Keanekaragaman dapat dikategorikan sebagai berikut (seperti yang diperbarui oleh Wilhelm dan Doris (1968) dalam Mason (1981)):

$H^{\prime}<2,3026$ : kurangnya variasi dan kurangnya stabilitas komunitas 2,3026

$<H^{\prime}>6,9078$ : keanekaragaman sedang dan kestabilan komunitas sedang

$\mathrm{H}^{\prime}>6,9078$ : stabilitas dan keragaman komunitas yang tinggi

\section{c. Indeks Keseragaman}

Rumus "Indeks Kemerataan" digunakan untuk menentukan Indeks Keseragaman (Odum, 1971).

$$
\mathrm{e}=\frac{H I}{\ln S}
$$

Dimana :

E : Indeks Keseragaman

$\mathrm{H}^{\prime}$ : Indeks Keanekaraman

$S$ : Jumlah Seluruh spesies

Indeks Keseragaman memiliki skala 0 sampai 1. Jika nilainya mendekati satu, maka distribusi individu antar spesies adalah sama. Jika distribusi individu antar spesies tidak merata atau jika ada spesies yang mendominasi, nilai E mendekati nol.

\section{d. Indeks Dominansi}

Indeks dominansi dihitung dengan menggunakan rumus "indeks of Dominance"dari Simpson (Odum, 1983).

$c=\sum\left(\frac{n i}{N}\right)^{2}$

Dimana:

C : Dominansi Simpson

ni : Jumlah individu tiap spesies

$\mathrm{N}$ : Jumlah individu seluruh spesies

dengan kriteria (Odum, 1971) sebagai berikut : $\mathrm{C}$ mendekati 0 tidak ada jenis yang mendominansi dan $\mathrm{C}$ mendekati 1 terdapat jen is yang mendominansi.

\subsection{Analisis Data}

Kuantitas, keragaman, keseragaman, dan dominasi hasil dipelajari secara deskriptif dalam bentuk grafik dan tabel. Untuk mengetahui variasi kerapatan zooplankton di ekosistem lamun, lamun - terumbu karang, dan terumbu karang, digunakan uji Analisis Varians satu arah (ANOVA). 


\section{Hasil dan Pembahasan}

\subsection{Komposisi Jenis Zooplankton}

Selama analisis laboratorium, struktur spesies zooplankton di daerah pengamatan yang ditemukan di perairan Pulau Maksar, Kota Baubau pada tiga stasiun lamun, lamun-karang dan karang ditemukan 18 spesies, yaitu Acrocalanus, Farella Campanula, Calanus, Tortanidae, Naupli Parvocalanus, Larva Longipedia, Labidocera, Clausocalanus, Eupasids, Microsetella, Oithona, Latreutes, Cyprid Balanus, Globigerina, Pagurus, Balanus, Neglecta, Copidognatus.

Tabel 1. Identifikasi Hasil Genus Zooplankton

\begin{tabular}{|c|c|c|c|c|c|}
\hline \multirow[b]{2}{*}{ No. } & \multirow[b]{2}{*}{ Kelas/Genus } & \multicolumn{3}{|c|}{ Spot/Jumlah } & \multirow[b]{2}{*}{ Jumlah ind/L } \\
\hline & & $\begin{array}{l}\text { Padang } \\
\text { Lamun }\end{array}$ & $\begin{array}{l}\text { Padang } \\
\text { Lamun - } \\
\text { Terumbu } \\
\text { Karang }\end{array}$ & $\begin{array}{c}\text { Terumbu } \\
\text { Karang }\end{array}$ & \\
\hline \multirow{12}{*}{1.} & & & Crustacea & & \\
\hline & Acrocalanus & 3 & 0 & 6 & 9 \\
\hline & Calanus & 4 & 1 & 3 & 8 \\
\hline & Clausocalanus & 1 & 0 & 3 & 4 \\
\hline & Eupasids & 9 & 1 & 2 & 12 \\
\hline & Labidocera & 8 & 0 & 4 & 12 \\
\hline & Larva Longipedia & 2 & 7 & 9 & 18 \\
\hline & Microsetella & 5 & 17 & 9 & 31 \\
\hline & Naupli Parvocalanus & 7 & 2 & 8 & 17 \\
\hline & Oithona & 1 & 23 & 9 & 33 \\
\hline & Tortanidae & 6 & 5 & 2 & 13 \\
\hline & \multicolumn{5}{|c|}{ Malacostraca } \\
\hline & Cyprid Balanus & 3 & 2 & 4 & 9 \\
\hline \multirow[t]{2}{*}{2.} & Latreutes & 1 & 12 & 2 & 15 \\
\hline & Pagurus & 1 & 1 & 3 & 5 \\
\hline \multicolumn{6}{|c|}{ Sarcodina } \\
\hline \multirow{3}{*}{3.} & Farella Campanula & 0 & 2 & 1 & 3 \\
\hline & Globigerina & 3 & 5 & 16 & 24 \\
\hline & \multicolumn{5}{|c|}{ Maxillopoda } \\
\hline 4. & Balanus & 6 & 2 & 1 & 9 \\
\hline \multicolumn{6}{|c|}{ Sagittoidea } \\
\hline 5. & Neglecta & 1 & 7 & 3 & 11 \\
\hline \multicolumn{6}{|c|}{ Archinida } \\
\hline 6. & Copidognatus & 1 & 6 & 1 & 8 \\
\hline & & umlah Total & & & 241 \\
\hline
\end{tabular}




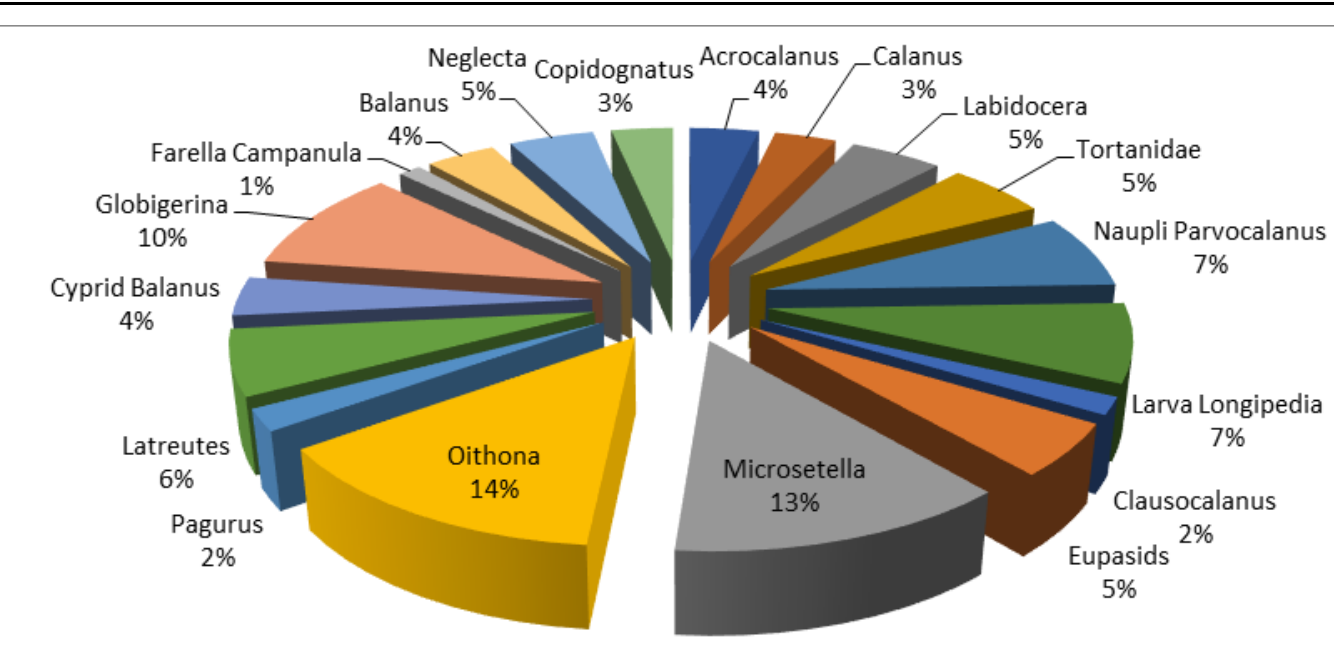

Gambar 1. Persentase jumlah genus zooplankton yang terdapat pada ekosistem padang lamun, padang lamun - terumbu karang, dan terumbu karang.

Hasil identifikasi genus zooplankton di semua lokasi spot (Tabel 1), ditentukan bahwa kepadatan genus keseluruhan adalah 241 ind/L untuk semua stasiun. Terdapat 1 genus dalam kelas Crustacea yang terdapat di semua stasiun yaitu Acrocalanus, Calanus, Labidocera, Tortanidae, Naupli Parvocalanus, Larvae Longipedia, Clausocalanus, Eupasids, Microsetella, Oithona yang didominasi oleh genus Oithona dengan jumlah 33 ind/L, dan 3 genus pada Pagurus, Latreutes, Cyprid Balanus merupakan salah satu genus yang terdapat pada kelas Malacostraca. Sarcodina, terdapat 2 genus termasuk Globigerina dan Farella Campanula. Genera lain yang termasuk dalam kelas termasuk Balanus, Neglecta, Copidognatus, yang semuanya ditemukan di kelas lain.

Oithona (25\%) mendominasi lokasi lamun-karang, sedangkan Eupasids $(15 \%)$ dan Globigerina (19\%) mendominasi stasiun lamun dan karang. Oithona adalah genus copepoda yang ditemukan di perairan Indonesia seperti laut di sepanjang pantai Jawa Timur, Lombok, dan Bali, menurut Sachoemar \& Hendiarti (2006). Kemampuan vertikal yang tinggi menyediakan sejumlah fungsi, sehingga mudah ditemukan dan berlimpah di berbagai lokasi.

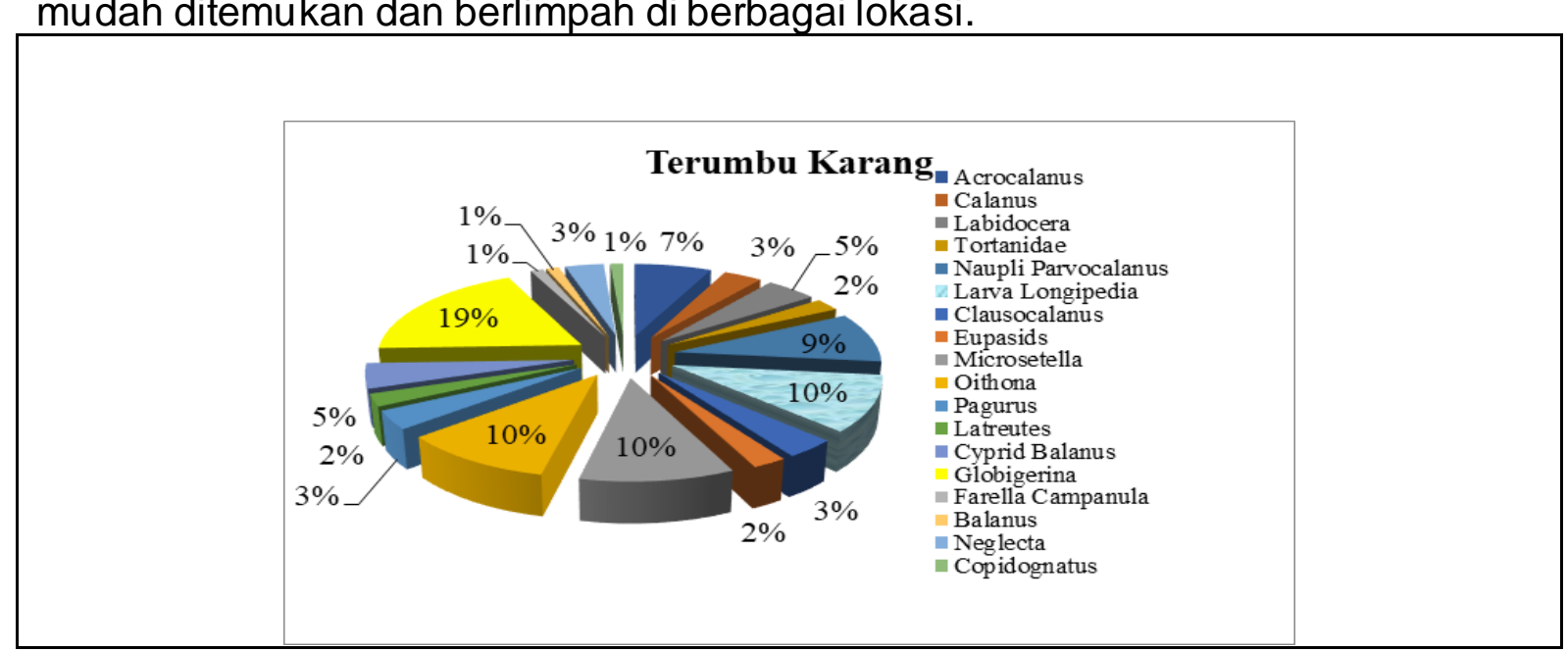




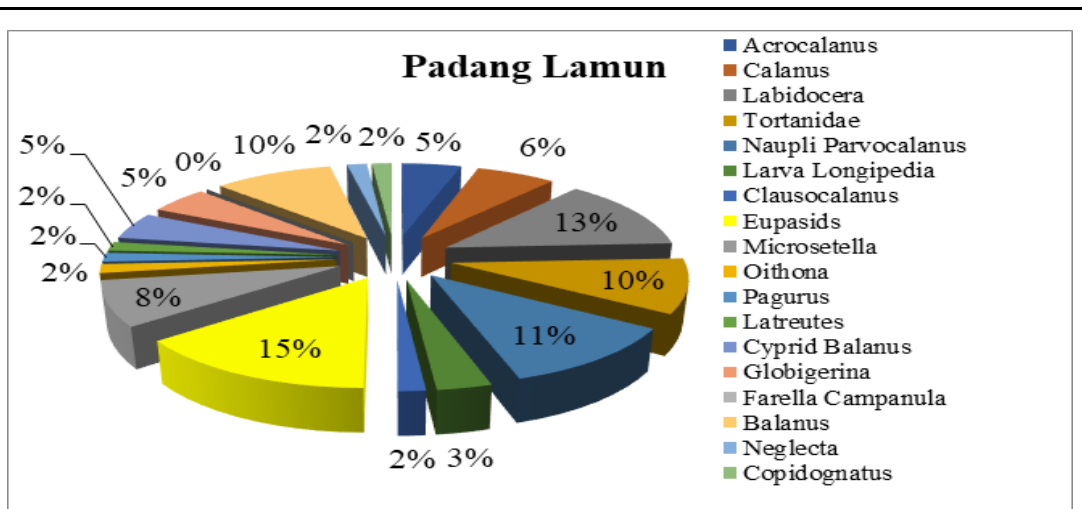

Gambar 2. Persentase Komposisi Spesies di Setiap Lokasi Spot

Genus Oithona ditemukan memiliki kepadatan zooplankton tertinggi berdasarkan jumlah lokasi spot yang dikunjungi, terhitung $25 \%$ dari semua individu. Genus Oithona melimpah dan banyak digunakan sebagai pakan hidup organisme laut, termasuk ikan air asin, sebab kandungan protein dalam genus Oithona lebih tinggi, yang berperan penting dalam mendukung sebagian besar kelangsungan hidup dan laju pertu mbuhan organisme laut (Munandar et al., 2016). Akibatnya, tingkat kelulusan dan tingkat pertumbuhan pada ikan yang diberi pakan yang mengandung Oithona tinggi, demikian pula tingkat pertumbuhannya.

Oithona merupakan zooplankton yang diklasifikasikan kedalam (Novianto \& Efendy, 2020):

Kingdom : Animalia

$\begin{array}{ll}\text { Filum } & \text { : Arthtropoda } \\ \text { Subfilum } & \text { : Crustacea } \\ \text { Kelas } & \text { : Maxillopoda } \\ \text { Subkelas } & \text { : Kopepoda } \\ \text { Ordo } & \text { : Eucopepoda } \\ \text { Sub Ordo : Cyclopoida } \\ \text { Family } & \text { : Cyclopoidae } \\ \text { Genus } & \text { : Oithona }\end{array}$

\subsection{Kelimpahan zooplankton}

Hasil temuan penelitian yang dilakukan di perairan laut Pulau Makassar, Kota Baubau. Ada 18 genus zooplankton yang terdeteksi, dengan konsentrasi genus yang bervariasi di setiap lokasi (Gambar 3).

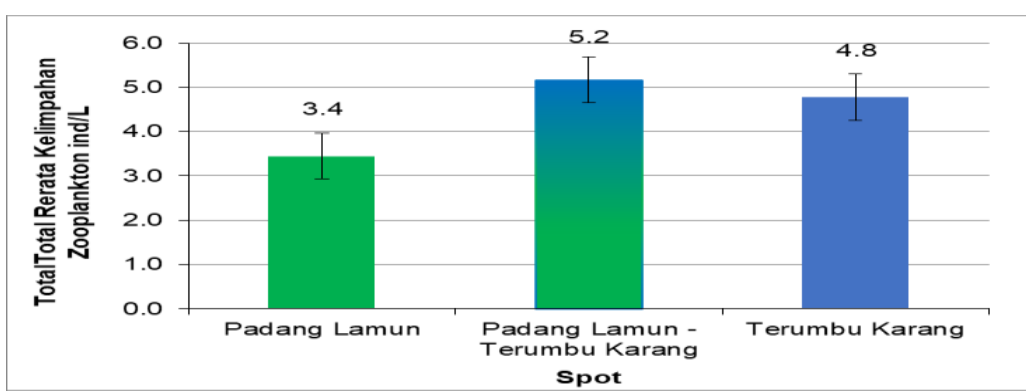

Gambar 3. Rata-rata Total Persentase Kelimpahan Zooplankton Setiap Lokasi Spot 
Hasil uji Analysis of Variance (ANOVA) menunjukkan bahwa tidak terdapat perbedaan kelimpahan zooplankton yang signifikan antar lokasi spot $(p>0,05)$.

Meskipun tidak ada perbedaan yang signifikan dalam kelimpahan zooplankton di seluruh stasiun, proporsi kelimpahan zooplankton di stasiun lamun karang lebih besar daripada di dua lingkungan lainnya. zooplankton di stasiun lamun-karang diperkirakan lebih banyak daripada di dua lokasi lainnya. Philipus et al. (2014) menyatakan Laju perkembangan ikan dan jumlah zooplankton menunjukkan bahwa lingkungan lamun adalah tempat zooplankton paling melimpah.

Menurut Rombetasik et al (2020) jika dibandingkan dengan habitat perairan dangkal lainnya seperti ekosistem bakau dan terumbu karang, padang lamun memiliki produksi primer terbesar.

\section{3 ndeks Keanekaragaman (' $\mathrm{H})$}

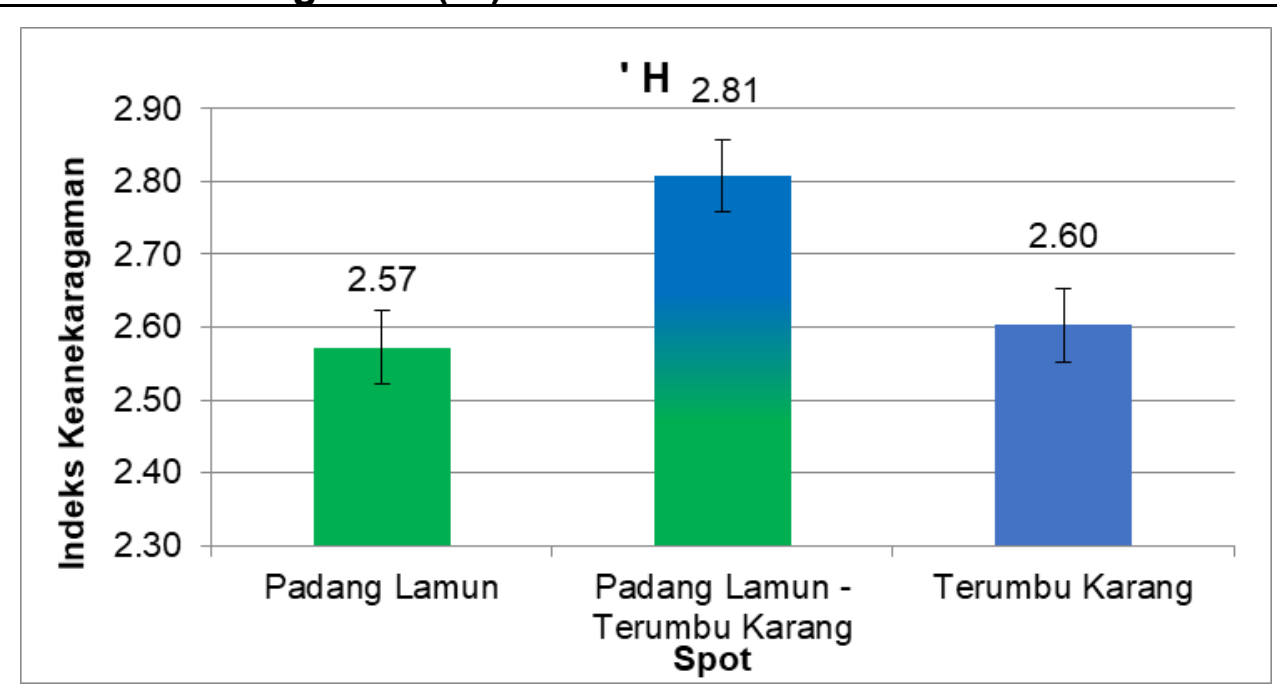

Gambar 4. Setiap lokasi memiliki indeks keanekaragaman yang berbeda.

Berdasarkan nilai indeks keanekaragaman (Gambar 4) yang terdapat di perairan Pulau Makasar kota Baubau cenderung tidak stabil karena keanekaragamannya yang rendah. Indeks keanekaragaman yang tinggi menunjukkan lingkungan yang seimbang dan berperan penting dalam men gawasi kecenderungan yang sama merugikan komunitas organik yang terdiri atas tumbuhan dan hewan, bersama habitatnya, sedangkan spesies yang tampak menonjol dalam suatu komunitas menunjukkan kekuatan spesies tersebut dibandingkan dengan spesies lain (Dhianthani 2003). Ekologi yang tidak seimbang akan berdampak pada makanan alami, dan jika makanan alami tidak tersedia, kelangsungan hidup larva organisme akan terancam. Jika dibandingkan dengan iklim sedang, keanekaragaman zooplankton lebih rendah di daerah tropis (Sulastri, 2009). 


\subsection{Indeks Keseragaman ('E)}

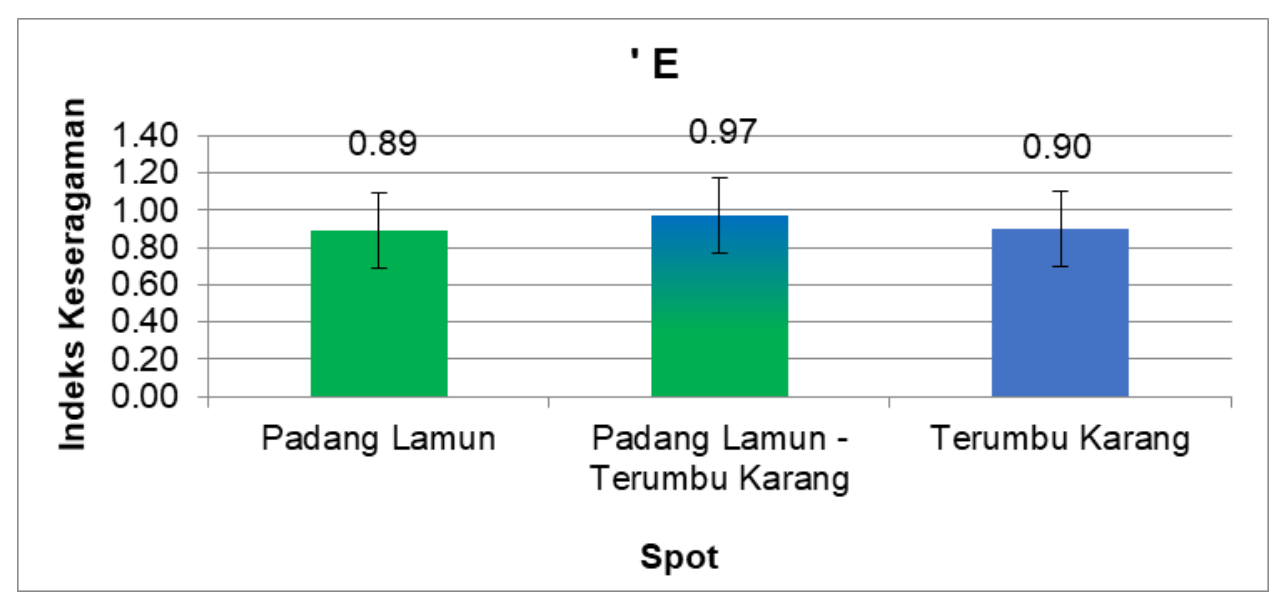

Gambar 5. Indeks Keseragaman di Tiap Spot

Hasil analisa indeks keseragaman zooplankton pada Perairan Pulau makasar Kota Baubau pada Spot lamun - karang keseragamannya tinggi , pada daerah karang nilai keseragamannya labil, sedangkan pada daerah lamun nilai indeks menunjukan bahwa Spot ini memiliki keseragaman yang kurang dikarenakan ada beberapa jenis zooplankton yang mendominasi pada daerah tersebut. (Gambar 6). Sastrioajie et. al (2012) menyatakan kategori nilai indek keseragaman (e) yaitu apabila nilai $0,00<\mathrm{e}<0,50$ komunitas dalam kondisi tertekan, nilai $0,50<\mathrm{e}<0,75$ komunitas dalam kondisi labil dan nilai $0,75<\mathrm{e}<1,00$ komunitas dalam kondisi stabil. Berdasarkan data diatas dapat dilihat bahwa pada Stasiun lamun - karang dan karang memiliki keseragaman zooplankton yang labil - stabil.

\subsection{Indeks Dominasi}

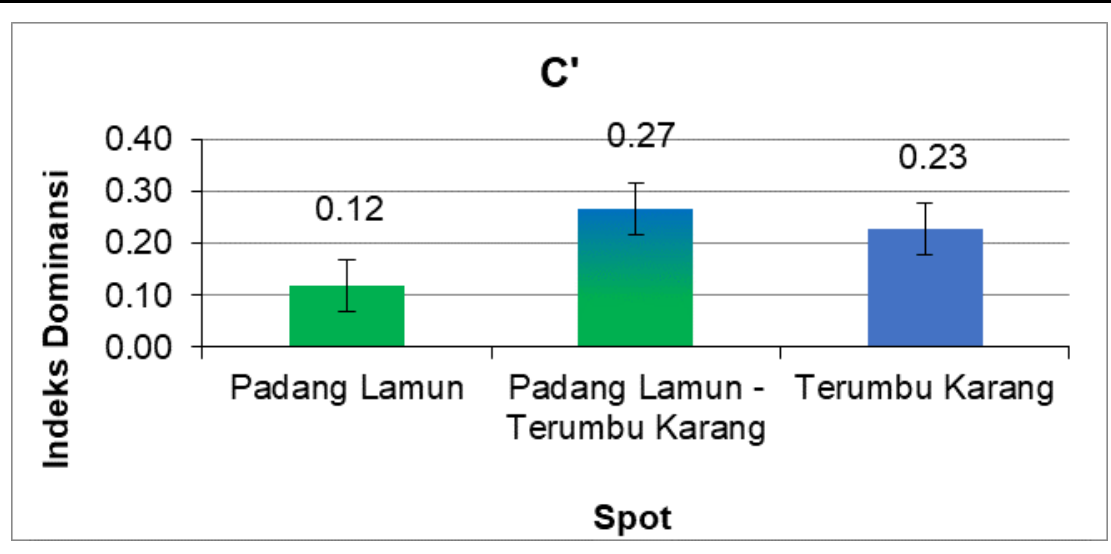

Gambar 6. Indeks Dominasidi Tiap Spot

Pada analisis dapat diamati pada Gambar 6 bahwa spot padang lamun, padang lamun - terumbu karang, dan terumbu karang menunjukkan tidak ada spesies yang mendominasi, kecuali stasiun lamun. Menurut Sastrioajie et. al (2012), nilai indeks dominasi (D) berada pada kelompok rendah saat $0,00 \mathrm{D} 0,50$, kategori sedang saat 0,50 D 0,75, dan dominasi ekstrim saat 0,00 D 1,00.

Dengan demikian, keseimbangan populasi zooplankton secara keseluruhan di perairan laut pulau Makasar Kota Baubau menunjukkan kondisi perairan yang umumnya menguntungkan. Secara umum, jika suatu komunitas akuatik memiliki nilai $H^{\prime}$ dan e yang tinggi, nilai $D$-nya rendah. Jika nilai $H^{\prime}$ dan e rendah, maka nilai 
D tinggi, menunjukkan bahwa suatu spesies memiliki dominasi atas spesies lain, dan dominasi yang cukup signifikan akan menghasilkan komunitas yang tidak stabil atau tertekan (Tampi et al., 2021).

Menurut Odum (1993), kepunahan satu spesies mendominasi yang mengakibatkan perubahan yang signifikan tidak hanya pada komunitas biotik spesies tersebut, tetapi juga pada habitat fisiknya. Dominasi sejenis zooplankton mungkin menunjukkan bahwa perairannya kotor atau tidak menguntungkan, hanya memungkinkan beberapa spesies untuk beradaptasi dengan keadaan ini. Dominasi suatu organisme merupakan salah satu indikator yang digunakan untuk menilai kualitas suatu badan air.

\section{Kesimpulan}

Dari tiga lokasi tertinggi ditemukan 18 genera zooplankton yang termasuk dalam kelompok Crustacea. Dengan kelimpahan 33 ind/l, genus Olthona mendominasi perairan Pulau Makasar Kota Baubau. Ketiga lokasi, tidak ada variasi kepadatan zooplankton yang terlihat.

\section{Daftar Pustaka}

Castro, M., \& Huber, M. E. (2007). Marine Biology. MeGraw-Hill Companies Inc.

Japa, L., Suripto, \& Mertha, I. G. (2013). Hubungan Kuantitatif Fitoplankton Dan Zooplankton Perairan Suaka Perikanan Gili Ranggo Teluk Serewe Lombok Timur. Jurnal Biologi Tropis, 13(1).

Munandar, A., Murwani, S., \& Agustrina, R. (2016). GROWTH OF Oithona sp. THAT GIVE WITH NATURAL FOOD Nannochloropsis sp., Isochrysis sp., and COMBINATION. Jurnal Biologi Eksperimen Dan Keanekaragaman Hayati, 3(2), 1-6.

Novianto, A., \& Efendy, M. (2020). Analysis of Density of Copepod (Oithona sp.)

Based on the Difference of Salinity (Case Study: Sundak Aquaculture Work Unit of Gunungkidul Regency Special Region of Yogyakarta). JUVENIL: Jurnal IImiah Kelautan Dan Kehutanan, 1(1).

Philipus, U. B. ., Sri, R., \& Retno, H. (2014). Komposisi dan Kelimpahan Plankton di Perairan Kayome Kepulauan Togean Sulawesi Tengah. Journal Of Marine Research, 3(4), 447-455. http://ejournal-s1.undip.ac.id/index.php/jmr.

Raza'I, T. S. (2017). Identifikasi Dan Kelimpahan Zooplankton Sebagai Sumber Pakan Alami Ikan Budidaya Di Perairan Kampung Gisi Desa Tembeling Kabupaten Bintan. Jurnal Intek Akuakultur, 1(1), 27-36.

Revika, Pujiono, W. ., \& Siti, R. (2016). Composition and Abundance Fish of Larvae and Juvenile in around Estuary of Tulung River, Demak. Journal Of Maquares Management Of Aquatic Resources, 5(2), 35-42.

Rombetasik, B., Lalamentik2, L. T. X., \& Lalamentik2. (2020). Struktur Komunitas Lamun di Perairan Tasik Ria Kecamatan Tombariri, Kabupaten Minahasa. Jurnal Ilmiah Platax, 7(1).

Sulastri. (2009). Karakteristik Komunitas Fitoplankton dan Faktor Lingkungan Danau-Danau Kecil di Pulau Jawa. J. Lit. Perikan. Ind, 15(2).

Tampi, K. K. E., Rimper, J. R. T. S. ., Warouw, V., Lumoindong, F., Agung, B. W., Medy Ompi, A. S., \& Wantasen. (2021). Bioindeks Zooplankton Di Perairan Pulau Bunaken. Jurnal Pesisir Dan Laut Tropis., 9(1). 